\title{
Methanol as a Main Fuel to Replace Gasoline Without Global Warming
}

\author{
John O’M. Bockris
}

Department of Chemistry, Texas A\&M University, Department of Chemistry, University of Pennsylvania, 10515 S.W. $55^{\text {th }}$ Place, Haile Plantation, Gainesville, Florida, 32608, USA

\begin{abstract}
The world temperature will increase by approximately $8^{\circ} \mathrm{C}$ by 2100 . This would bring the temperature in parts of the Middle East to values causing heat stroke and death. Methanol made from pure $\mathrm{H}_{2}$ and $\mathrm{CO}_{2}$ removed from the atmosphere would cause no global warming and could be made from inexhaustible compounds on the surface of the earth. Cheaper ways of making this fuel may be available.
\end{abstract}

Keywords: Tar sands, $\mathrm{CO}_{2}$ from the atmosphere, copper zinc catalyst, no warming.

\section{INTRODUCTION}

The oil imperium claims to have a solution to the exhaustion of the normal oil supply. It wants to bring forth what might be called the old guard, i.e., resuscitation from sources known to oil explorers, particularly in Alberta, Canada, which contain sand mixed with around 10 percent by weight of oil [1].

The world is using per day 0.1 billion barrels of gasoline [2].

Bitumen sands are called crude bitumen, to distinguish them from normal hydrocarbons. Total natural bitumen reserves are estimated at 249.67 billion barrels $\left(39.694 \times 10^{9} \mathrm{~m}^{3}\right)$ globally, of which 176.8 billion barrels $\left(28.11 \times 10^{9} \mathrm{~m}^{3}\right)$, or 70.8 percent are in Canada [3].

Higher estimates of oil from tar sands have been three trillion barrels. Based on the figures for the world's consumption of oil, and the highest estimate of three trillion barrels of oil from tar sands, the tar sands could last for several decades but global warming would have made us abandon oil long before that.

I have confidence in the tar sands lower figure. The higher figure represents a conclusion and it was calculated by assuming that all the deposits found at first would yield oil to the same extent as those which have been carefully examined in Alberta.

The reliance on the tar sands needs more investigation. Oil use will be limited in the future by the rise in world temperature. A government audit [4]

*Address corresponding to this author at 10515 S.W. $55^{\text {th }}$ Place, Haile Plantation, Gainesville, Florida, 32608, USA; Tel: 352-335-3843; Fax: 352-3356925; E-mails: jbockris@cox.net and schulz77870@aol.com confirmed there will be global warming estimated in fifteen to thirty year periods (See Table $\mathbf{1}$ ).

The time of the use of the tar sands will be limited by an accompanying rise in temperature by about 2090, which use of oil from the tar sands will contribute. The point of being too hot is something not yet faced. As this temperature rises, dehydration and heat stroke will become life threatening.

Once the voters feel the warming and realize that continuing the use of oil products is making life too hot, they will change their minds about continuing gasoline, natural gas, or coal. Members of Congress will then decide that it is passing a heavy tax on carbon or risking the elected seats they hold. Europeans have been paying about $\$ 8 /$ gallon for gasoline for several years. Some half of this goes to alleviate their debt.

In preparation for this, an advantageous substitute for oil is proposed. Readers understand that this suggestion would lead to an easy change to non- $\mathrm{CO}_{2}$ producing fuels - perhaps in a decade for the U.S.A.

\section{HISTORY OF METHANOL AS A FUEL}

I recommended a Methanol Economy in 1975 [5]. Methanol has advantages over hydrogen, being a liquid.

In 1975, global warming had not yet taken the place of smog formation [6]. In fact, the final association of $\mathrm{CO}_{2}$ in the atmosphere and absorption of some of the light reflected from the earth was found to be the main cause of the anthropogenic contribution to global warming according to a government committee [7]. This conclusion took into account the contribution made by the sun itself, which undergoes a well-defined eleven year cycle. 
Table 1: $\mathrm{CO}_{2}$ Concentration in the Atmosphere Causes the World Temperature to Increase. Using Various Factors, the Table Represents an Estimate of Increase in Temperature as the $\mathrm{CO}_{2}$ Levels Accumulate. Source: The Intergovernmental Panel on Climate Change [4]

\begin{tabular}{|c|c|c|}
\hline $\begin{array}{c}\text { Peaking Year For } \mathbf{C O}_{2} \\
\text { Emissions }\end{array}$ & $\begin{array}{c}\mathbf{C O}_{2} \text { Concentrations At Stabilization } \\
(\mathbf{2 0 0 5}=\mathbf{3 7 9} \mathbf{~ p m )}\end{array}$ & $\begin{array}{c}\text { Global Average Temperature Increase Above Pre-Industrial At } \\
\text { Equilibrium, Using "Best Estimate" Climate Sensitivity }\end{array}$ \\
\hline Year & $\mathbf{p p m}$ & $\mathbf{C}$ \\
\hline \hline $2000-2015$ & $350-400$ & $2.0-2.4$ \\
\hline $2000-2020$ & $400-440$ & $2.4-2.8$ \\
\hline $2010-2030$ & $440-485$ & $2.8-3.2$ \\
\hline $2020-2060$ & $485-570$ & $3.2-4.0$ \\
\hline $2050-2080$ & $570-660$ & $4.0-4.9$ \\
\hline $2060-2090$ & $660-790$ & $4.9-6.1$ \\
\hline
\end{tabular}

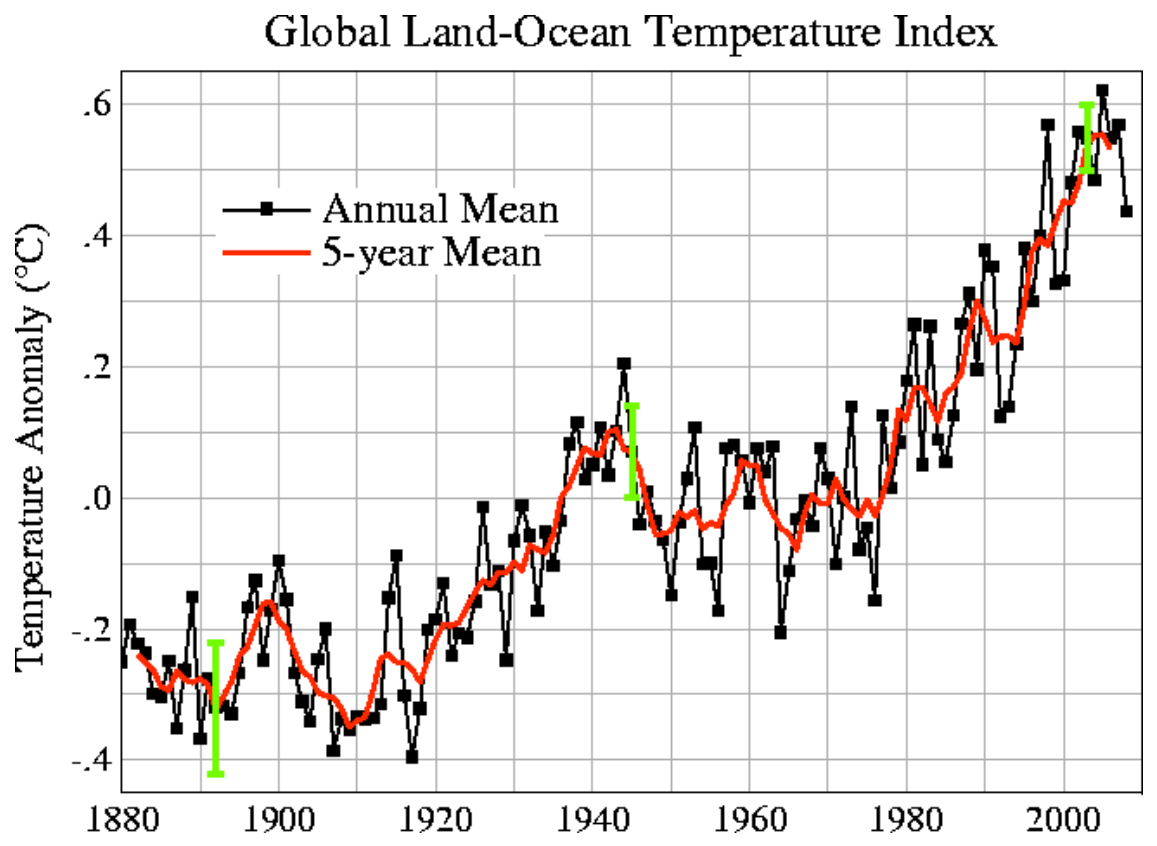

Figure 1: http://ossfoundation.us/projects/environment/global-warming/myths/images/temperature- NASA GISS 2008 Global Land Ocean Temperature Index - Shows the global average temperature increase/rise since 1880-2008 Source: http://data.giss.nasa.gov/gistemp/graphs/Fig.A2.Irg.gifrecords/2008_global_land_ocean_temperature_index.gif/view

In 1980, I again compared methanol with hydrogen and electricity [8]. Methanol seemed to be a substitute for gasoline, because it could be produced in large amounts through simple constituents available on the earth's surface, without exploration. Only a minor modification would be needed to the IC engine but the threat of smog pulled my 1980 recommendation of what to develop over towards hydrogen [9]. A Hydrogen Economy had been described in 1972 [10].

T. Nejat Veziroglu played a rising part in the development of hydrogen. He started a journal devoted to Hydrogen and organized biennial meetings throughout the world. The International Journal of Hydrogen Energy has continued to publish articles in this field. Support for a Hydrogen Economy is high in
Germany where the Mercedes Company supports the development partly because hydrogen is a fuel for cost saving fuel cells [11].

\section{THE CONTRIBUTIONS OF GEORGE OLAH AND THE REBIRTH OF THE METHANOL ECONOMY}

The year 2006 saw the publication of the first of two editions of a book by George Olah, G.K. Surya Prakash and Alain Goeppert, Beyond Oil and Gas: A Methanol Economy [12]. Olah is a Nobel Laureate in organic chemistry. He and his coauthors offer a challenge to hydrogen.

Olah et al., encourage the prospects of methanol as a fuel described in detail in their books. They stress the advantages of methanol in driving IC engines. They 


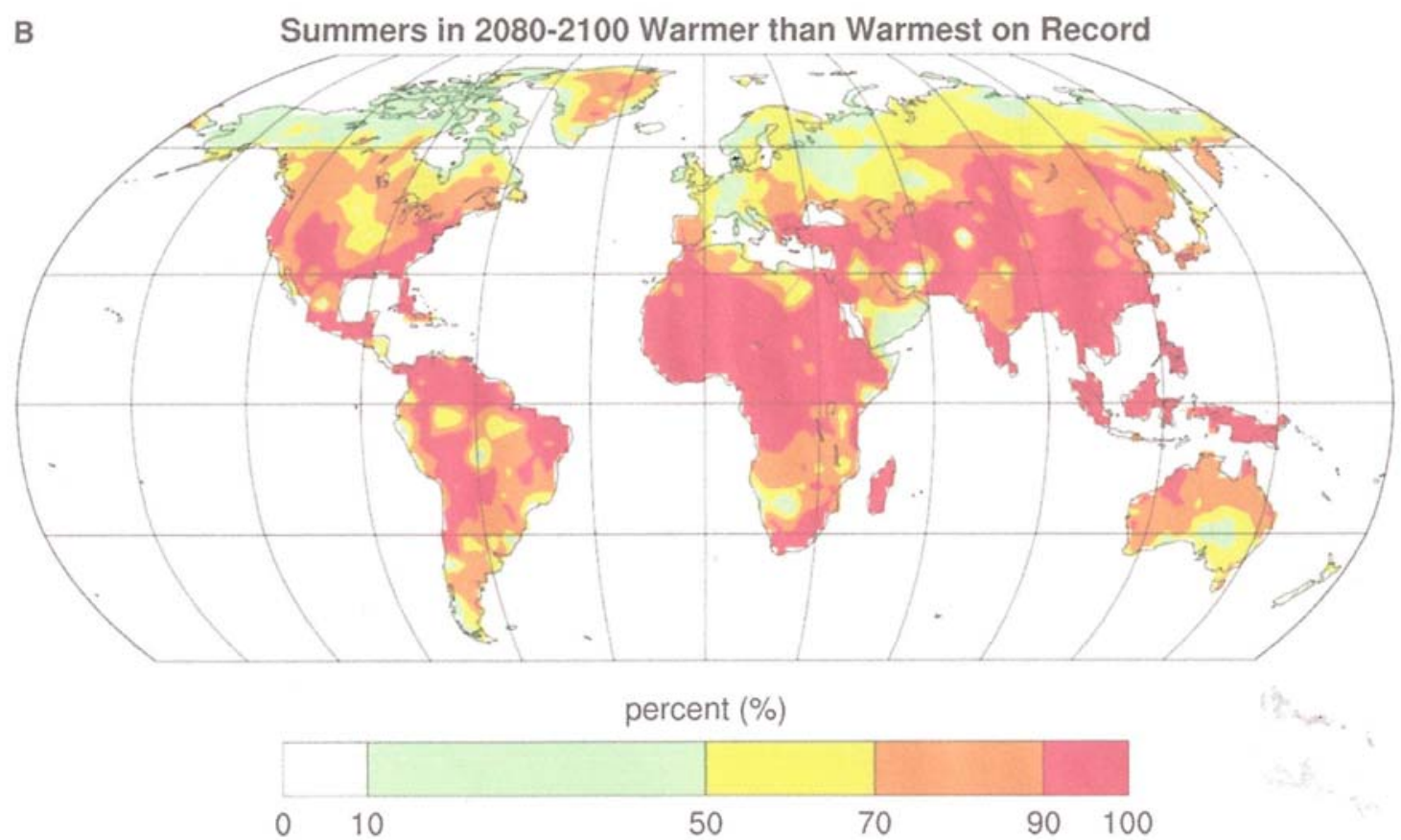

Figure 2: Likelihood (in percent) that future summer average temperatures will exceed the highest summer temperature observed on record for 2090. For example, for places shown in red there is greater than a $90 \%$ chance that the summeraveraged temperature will exceed the highest temperature on record (1900-2006).

look towards the Hydrogen Economy as an alternative but develop the counter case which stresses the qualities of methanol, being a liquid.

Olah and methanol have turned out to be a strong challenge to hydrogen. However, hydrogen by 2012 was being seen by several automotive manufacturers because fuel cells give about twice times in efficiency to drive an electric car than with batteries.

In 2009, Olah, Goeppert and Prakash, produced a second edition of the same book but considerably extended. Automotive manufacturers stress their readiness with cars which could be run at half the cost if the fuel for fuel cells (hydrogen) were available. Olah, et al., pressed the fuel cell aspect of methanol and developed research in a government laboratory towards increasing the efficiency.

Writing in 2012, a change towards methanol which might have been expected as a result of Olah's books (2009), had not yet been seen. The reluctance towards a change to methanol was based not only on the possible competition from Alberta's tar sands, but also on the fact that conversion to methanol might still threaten global warming (see Figure 1).

In the meantime (2012), our present administration intends to build an underground pipeline system, a
2,163 mile pipeline from Alberta to Texas to reach the refineries available for a third stage in the refining of oil from tar sands. It would be to transport diluted bitumen ("dilbit") from the Athabasca oil sands region to multiple destinations in the United States, including refineries in Illinois, the Cushing oil distribution hub in Oklahoma, and proposed connections to refineries along the Gulf Coast of Texas [13]. This move to work on this massive project could have been avoided with the Olah books in existence showing the advantages of easily produced methanol.

\section{METHANOL MADE FROM $\mathrm{CO}_{2}$ FROM THE ATMOSPHERE $=$ METHANOL}

The advantages of methanol compared with oil and gasoline is based on the ease of production and handling. Gasoline has to be extracted and gradually transformed from the tar sands. There is a dark side behind the sands which was helped by British Petroleum's effort to bore down beneath the seabed in the Gulf of Mexico giving rise to an accident with massive repercussions on the availability of this part of the world towards further exploration.

All this desperate seeking of oil helped going to the tar sands in spite of the fact that there had been available a solution in Olah's book, 2006. Is this an example of how ownership blinds the relevant groups 
whilst a better alternative is explained in the Olah presentations? From the point of view of the oil imperium, they own the tar sands and the oil which they hope to sell.

Methanol is a fuel which can be easily created by a chemical synthesis using compounds cheaply available in any country and further, if it is made in the correct way, it can drive an IC engine with little modification. Its use would end the threat of increasing temperatures to drive us off the earth.

Next to consider, what form of methanol would it be best to develop? It too, like hydrogen, can be made into a zero-carbon fuel. Consider the following synthesis of methanol:

$$
\mathrm{CO}_{2 \mathrm{AT}}+3 \mathrm{H}_{2} \stackrel{\mathrm{CuZn}}{\longrightarrow} \mathrm{CH}_{3} \mathrm{OH}_{\mathrm{At}}+\mathrm{H}_{2} \mathrm{O}
$$

To achieve this synthesis of methanol, one needs $\mathrm{CO}_{2}$ available in a stream which would correspond to the stream which can be made from an electrolyzer producing hydrogen. The $\mathrm{CO}_{2}$ needed is only one-third of the hydrogen in volumes of moles/unit time and at three times greater rate at which the hydrogen could be produced electrically (See Equation 1).

Let us tackle the problem of the $\mathrm{CO}_{2}$ stream first.It is easy to look to the air itself for the origin of the $\mathrm{CO}_{2}$. However, within the air the $\mathrm{CO}_{2}$ is present at $391 \mathrm{ppm}$ as of 2012 (increasing $1 / 2$ percent per year) [14] and this means that the $\mathrm{CO}_{2}$ is dilute in air so it's expensive to isolate. A better way to obtain the $\mathrm{CO}_{2}$ is to use naturally available compounds which have already trapped the carbon. Consider biomass (wood, trees, plants) as the biggest source of carbon from the atmosphere which enters them when they spontaneously synthesize in the presence of light and thus $\mathrm{CO}_{2}$ in these compounds would indeed be equivalent to $\mathrm{CO}_{2}$ from the atmosphere and obtaining it from carbonaceous compounds is very simple: They just need heating. Materials containing carbon from the atmosphere are plentiful. They include not only biomass, but also carbonaceous rubbish, farm sewage and etc. We can then be sure that the $\mathrm{CO}_{2}$ that we use to synthesize methanol has in it carbon which we have to remove from the atmosphere. We are doing the removal from the atmosphere of $\mathrm{CO}_{2}$ in the synthesis of methanol. This allows the combination, taking $\mathrm{CO}_{2}$ and hydrogen, to form methanol according to Equation 1.

We have to obtain sufficient amounts of one of these naturally available carbon containing compounds and then deliver it to a refinery. There is no need for chemical treatment. The refinery would process the carbon-containing compound into a form such as pellets or bricks, which can then be transported to a fuel station to yield the desired $\mathrm{CO}_{2}$ on application of heat there.

This is what is needed for the combination reaction indicated in Equation (1) and occur underneath the

\section{MAKING METHANOL MT $_{\text {T }}$}

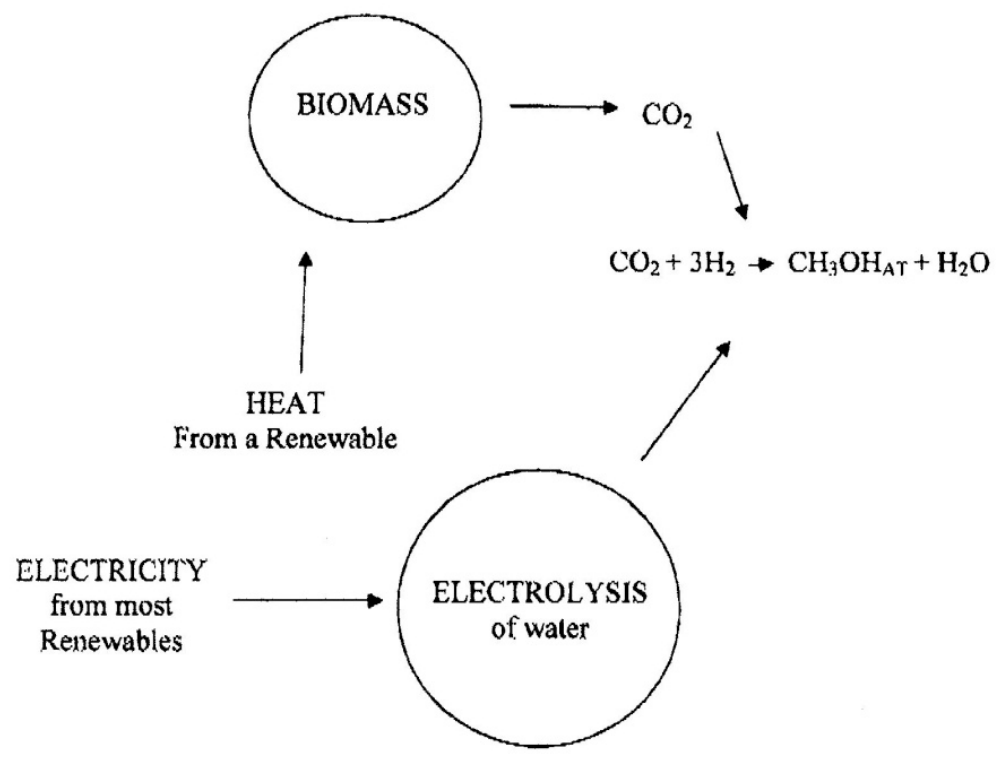

Figure 3: Making Methanol $\left.\right|_{\text {At. }}$ 
former gas stations with the hydrogen from the electrolyzer originating in water.

How to get the hydrogen? Clearly, this comes from the electrical synthesis so well-known and originated by Michael Faraday in 1835 and it's generally called "electrolysis" [15]. One has to be careful here as to the source of electricity by which one drives the electrolyzer because it must not involve a fossil fuel, otherwise we are back with carbon again.

The most attractive source of electricity is the socalled "enhanced geothermal" which a project in the late state of development in Australia takes heat directly in the earth and produces no carbon-containing compounds on the way to its production of electricity and steam. Professor Tester compiled a report at MIT [16] in which he ventured to a committee-backed cost of 3.9 cents $/ \mathrm{kWh}$ for electricity from a geothermal source.

Another means for producing electricity without $\mathrm{CO}_{2}$ is in countries where there is massive availability of solar light. It's difficult to ignore solar in spite of the diurnal variation.

Wind energy might eventually be cheaper than enhanced geothermal. There are wind maps of the United States which show that Middle America is the best place to have wind-operated turbines. The sea offers wind and space.

Roberts [17] has been the leading engineer in taking a helicopter equipped with four rotors up to 15,000 feet where wind has been measured at a steady $75 \mathrm{mph}$. The problem however is that the rotors which would withstand such winds are not yet with us. If this route were pursued, the wind energy would have to be stored in summer months when the wind drops down.

What we can do with the methanol made in this way, i.e., methanol from the atmosphere? When it is used as a fuel, it is bound to reproduce the $\mathrm{CO}_{2}$ back into the atmosphere from which it was removed in the synthesis. This justifies the claim that this methanol is a zero-carbon method. It does not increase global warming. A change as soon as possible to limit the buildup of $\mathrm{CO}_{2}$, which will develop due to the use of gasoline.

A limit for people to work normally is a world temperature of about $90^{\circ} \mathrm{F}$, although many would say it is less. I suggest we move quickly because it is liable that we shall run into this temperature in summers before the end of the century. (A world conversion will be needed.)

\subsection{Simplified Synthesis}

Alternatively, it may be possible to develop methanol $_{A t}$ without the use of electricity. Steam reforming of natural gas is a very well-known reaction (See Equation 2).

$$
\mathrm{CH}_{4}+\underset{(\text { steam })}{2 \mathrm{H}_{2} \mathrm{O}} \longrightarrow \mathrm{CO}_{2}+4 \mathrm{H}_{2}
$$

$\mathrm{CO}_{2}$ and $\mathrm{H}_{2}$ may be reacted together over a CuZn catalyst which is particularly for that reaction to form methanol (see Equation 3):

$$
3 \mathrm{H}_{2}+\mathrm{CO}_{2} \stackrel{\mathrm{CuZn}}{\longrightarrow} \mathrm{CH}_{3} \mathrm{OH}+\mathrm{H}_{2} \mathrm{O}
$$

There is less experience with the steam reforming reaction as the beginning reaction for the electrical synthesis of methanol. It represents an escape from the cost of electricity.

However, a further simplification can be considered. In earlier work, I have pointed out that the use of $\mathrm{CO}_{2}$ can be done via biomass but also from carbonaceous wastes, including, e.g., wastes obtained on carbonaceous substances at much higher temperatures than that used for the normal steam reforming reaction. A final cost reduction might be achieved by taking the product of a reaction of carbon wastes and running what would contain an appropriate ratio of $\mathrm{CO}_{2}$ and plenty of $\mathrm{H}_{2}$ over the methanol forming catalyst $\mathrm{CuZn}$.

The expected reaction from this mixture will of course be less than the product of the original design when pure $\mathrm{CO}_{2}$ and pure $\mathrm{H}_{2}$ are reacted together. It might still be valuable because the earlier part of the synthesis would be at much lower cost. (Cf., the extraction of only 10 percent of oil from the sands which are now being exploited because we have exhausted our oil resources).

So the product substantially less than pure methanol would now be treated to extract the pure methanol from the mixture obtained by running the product of an enhanced steam reforming reaction over the CuZn catalyst.

The cost would be less than that obtained when the pure versions of $\mathrm{CO}_{2}$ and $\mathrm{H}_{2}$ are reacted together. 
However, the cost of this product might be of economic interest.

\subsection{Some Suggestions for Practical Arrangement of a Methanol ${ }_{A t}$ Economy}

One of the criteria for choosing the next fuel is the cost and time it will take to make the changeover from oil to the new fuel (nuclear? hydrogen?). This could be done with little fuss if we are going to methanol. In fact during WWII people who got ahold of methanol, particularly those in university laboratories, used to add methanol to their gasoline which was in short supply by its rationing.

Thus, one proposition is to make the synthesis in the enhanced methanol production underneath the energy stations (the former gas stations) and this has to be tried out and developed economically. Pure hydrogen is easily produced so long as one has a carbon-free source of electricity and a $\mathrm{CO}_{2}$ stream to use it as described above.

1. Hydrogen: One could obtain hydrogen free from $\mathrm{CO}_{2}$ if it were developed by electrolysis using electricity made from sources from, e.g., enhanced geothermal, wind, solar, tidal, etc. Water is easily available in all gas stations and the synthesis of methanol would take place there [18].

2. $\mathrm{CO}_{2}$ in a stream: Biomass would be heated to produce the $\mathrm{CO}_{2}$ stream. It needs organization to collect the biomass, etc. There must intervene a refinery to produce the biomass into pellets or bricks, and then ship this to the energy stations [19].

3. Combination of $\mathrm{CO}_{2}$ and Hydrogen: The reaction needs a catalyst [20] (Figure 3 ).

4. No Global Warming: The production of hydrogen and $\mathrm{CO}_{2}$ originated from the atmosphere will make methanol ${ }_{\mathrm{AT}}$. After use as a fuel, $\mathrm{CO}_{2}$ will be put back into the atmosphere. However, this is the $\mathrm{CO}_{2}$ we took away from the atmosphere to make the methanol ${ }_{\text {AT. }}$. No further accumulation of $\mathrm{CO}_{2}$ will occur if only methanol $\mathrm{AT}_{\mathrm{AT}}$ is used. Thus, methanol $_{A T}$ can be considered a zero-carbon fuel. Its large-scale application would not increase global warming, the major reason why we need to stop using oil and natural gas [21].

\subsection{Costs}

Preliminary cost estimates of making methanol from the atmosphere have been made. The first person to make a zeroeth approximation calculation was Rey Sidik of Case Western University. He came to $\$ 28 / \mathrm{GJ}$ [22]. Corresponding to this, Professor Keith from the University of Calgary stated that he was confident that methanol could be made somewhere between $\$ 20$ $\$ 30 / G J$ [23].

An analysis of the details of the calculations shows that it is much dependent on the cost of the electricity because this affects the cost of hydrogen. We have to wait for massive production from wind and see what cost that will be. There is a company located in Michigan [24] which has reduced the price of its wind power electricity and was selling it in 2007 at three cents/kWh. Of course Michigan is a relatively windy place, but there are plenty of wind pathways north to south in the center of the United States. As a Methanol $_{A T}$ Economy with zero global warming is not going to be active throughout the country for as little as a decade, this would give us time to produce the price of wind energy down to two cents/ kWh predicted by the Wind Association of the USA [25].

Comparing these costs of methanol $\mathrm{AT}_{\mathrm{AT}}$ with the cost of hydrogen needs broader consideration. Tapan Bose and Pierre Malbrunot, authors of the French-Canadian book Hydrogen [26] have made an extensive examination of the costs associated in producing hydrogen on a big scale. These authors have concluded that the cost of hydrogen in practice is $\$ 49 /$ GJ (about double the cost of the raw product from the electrolyzer).

The biggest expense lies in the fact that hydrogen is a gas and would need to be converted to electricity, whereas methanol ${ }_{A T}$ is ready for use as a fuel without any conversion. The two simplifications, avoiding the use of electricity would produce methanol at less than $\$ 20 / G J$.

It is clear that the estimates show methanol $\mathrm{AT}_{\mathrm{T}}$ at an advantage for $\$ 10-\$ 20 / G J$ less than hydrogen in practical use.

\section{CONCLUSIONS}

Methanol from the atmosphere is a perfect fuel. It is much like gasoline but can be made from natural products freely available on the earth's surface. Its components cannot exhaust or pollute. Using it will no 
longer contribute to an increase of the temperature of the earth's atmosphere (no increase in global warming).

\section{ACKNOWLEDGEMENTS}

Information gathering in 2012 for this paper was carried out by Joanna Kern who also contributed some clarification of the text. Ms. Kern is to be thanks for improving the document. Mrs. Patricia Schulz edited the final version, making clarifying changes to the text and is also to be thanked.

\section{REFERENCES AND NOTES}

[1] Campbell C. Oil Depletion - The Heart of the Matter, The Association for the Study of Peak Oil and Gas, 2008. http://www.hubbertpeak.com/campbell/theheartofthematter.p df

[2] Wikipedia, Global Strategic Petroleum Reserves, “...current consumption levels are neighboring 0.1 billion barrels $(16,000,000 \mathrm{m3}) \quad$ per day," http://en.wikipedia.irg/wiki/ global_strategic_petroleum_reserves, Retrieved October 20, 2012.

[3] Wikipedia, Oil Sands, http://en.wikipedia.org/wiki/oil_sands, Retrieved October 20, 2012.

[4] A. Pachauri RK, Reisinger A, Ed., Climate Change 2007: Synthesis Report, Contribution of Working Groups I, II and III to the Fourth Assessment Report of the Intergovernmental Panel on Climate Change, IPCC, 2007; ISBN 92-9169-122-4, http://www.ipcc.ch/publications_and_data/ar4/syr/en/contents .html;

B. Solomon S, Qin D, Manning M, Chen Z, Marquis M, Averyt KB, Tignor M, Miller HL, Eds. Climate Change 2007: The Physical Science Basis, Contribution of Working Group I to the Fourth Assessment Report of the Intergovernmental Panel on Climate Change, Cambridge University Press, 2007; ISBN 978-0-521-88009-1, http://www.ipcc.ch/ publications_and_data/ar4/wg1/en/contents.html (pb: 978-0521-70596-7).

C. Parry ML, Canziani OF, Palutikof JP, van der Linden PJ, Hanson CE, Eds., Climate Change 2007: Impacts, Adaptation and Vulnerability, Contribution of Working Group II to the Fourth Assessment Report of the Intergovernmental Panel on Climate Change, Cambridge University Press 2007; ISBN 978-0-521-88010-7, http://www.ipcc.ch/publications and_data/ar4/wg2/en/contents.html (pb: 978-0-521-70597-4);

D. Metz B, Davidson OR, Bosch PR, Dave R, Meyer LA, Eds. Climate Change 2007: Mitigation of Climate Change, Contribution of Working Group III to the Fourth Assessment Report of the Intergovernmental Panel on Climate Change, Cambridge University Press 2007; ISBN 978-0-521-88011-4, http://www.ipcc.ch/publications_and_data/ar4/wg3/en/content s.html (pb: 978-0-521-70598-1).

[5] Bockris JO'M. Electrochemical Production of Hydrogen as a Fuel. Cornell Symposium on Hydrogen Economy 1975; 143169.

[6] Wikipedia, Smog, http://en.wikipedia.org/wiki/smog, Retrieved October 25th, 2012.

[7] Bampton M. Anthropogenic Transformation, in Encyclopedia of Environmental Science, Alexander, D.E. and Fairbridge, R.W., Kluwer Academic Publishers, Dordrecht, The Netherlands, 2004.

[8] Bockris JO'M, Energy Options, Plenum, New York 1980; p. 204.
A. Methanol Fuel http://en.wikipedia.org/wiki/Methanol_fuel and http://en.wikipedia.org/wiki/CH3OH; Retrieved October 30, 2012.

B. Reed Tom B, Lerner RM. Methanol: A Versatile Fuel for Immediate Use. Science 1973-12; 182(4119): 1299-304. doi:10.1126/science.182.4119.1299. PMID 17733096. http://www.woodgas.com/Science1.pdf. Retrieved October 30, 2012.

http://dx.doi.org/10.1126/science.182.4119.1299

C. Hagen DL. Methanol: Its Synthesis, Use as a Fuel, Economics, and Hazards. Energy Research and Development Administration (ERDA) 1976-12; NTIS \#NP21727. Retrieved October 30, 2012.

[10] Bockris JO'M, Appleby J. The Hydrogen Economy - An Ultimate Economy, Environment This Month 1971; 1: 29.

[11] A. Mercedes-Benz eyeing introducing a sedan model hydrogen fuel cell vehicle around MY 201717 May 2012, http://www.greencarcongress.com/2012/05/simon20120517/comments/page/2/; Retrieved October 30, 2012.

B. Johnston B, Mayo MC, Khare A. Hydrogen: the energy source for the 21st century. Technovation 2005; 25(6): 56985. ISSN 0166-4972, 10.1016/j.technovation.2003.11.005. (http://www.sciencedirect.com/science/article/pii/S016649720 3002049). Retrieved October 30, 2012.

[12] Olah G, Goeppert A, Prakash S. The Methanol Economy, Wiley-VCH Verlag, First Edition 2006 and Second Edition 2009.

[13] Wikipedia, Keystone Pipeline, http://en.wikipedia.org/wiki/ Fuel_Cell_vehicle, Retrieved October 26, 2012.

[14] "...CO2 present in the air is at 391ppm as of 2012." Todd Sanford, Climate scientist in the Climate \& Energy Program at the Union of Concerned Scientists, former scientist at NOAA Earth System Research Laboratory.

[15] Wikipedia, Michael Faraday, http://en.wikipedia.org/wiki/ Michael_Faraday, Retrieved October 20, 2012.

[16] Tester JW, et al. The Future of Geothermal Energy, Impact of Enhanced Geothermal Systems (Egs) on the United States in the 21st Century: An Assessment, Idaho Falls: Idaho National Laboratory 2006; pp. 1-8 to 1-33. (Executive Summary), ISBN 0-615-13438-6, http://geothermal.inel.gov/ publications/future_of_geothermal_energy.pdf, retrieved 2007-02-07.

[17] Roberts BW, et al. Harnessing High Altitude Wind Power, IEEE, Sept. 2001 and Transactions on Energy Conversion 2007; 22(1).

[18] A. Andersen, and Fjellvåg. Elektrolyse. Store Norske Leksikon. 18 May 2010. http://snl.no/elektrolyse; Retrieved October 30, 2012.

B. Christensen N. Elektroplettering. Store Norske Leksikon. May 26. http://snl.no/elektroplettering; Davis.

C. Raymond E. Modern Chemistry. Austin, Texas: Holt, Rinehart, and Winston, 2005.

D. Kofstad Per K. Aluminium. Store Norske Leksikon. May 26.http://snl.no/aluminium; Kroposki, Levene, et al. "Electrolysis: Information and Opportunities for Electric Power Utilities."; National Renewable Energy Laboratory. May 26:1- 33.www.nrel.gov/hydrogen/pdfs/40605.pdf. Retrieved October 30, 2012.

[19] A. Jadhavm RA. Method And System For Capturing Carbon Dioxide From Biomass Pyrolysis Process, Chevron U.S.A. Inc. 2011.

B. JADHAV, Raja, A. WO/2011/071768, http://www. sumobrain.com/patents/WO2011071768.html Retrieved October 30, 2012.

[20] Gu W, Shen J-P, Song C. Hydrogen Production From Integrated Methanol Reforming Over $\mathrm{Cu}-\mathrm{Zno} / \mathrm{Al} 2 \mathrm{o} 3$ And Pt/Al2o3 Catalysts For Pem Fuel Cells, Clean Fuel and Catalysis Program, The Energy Institute and Department of 
Energy \& Geo-Environmental Engineering, The Pennsylvania State University http://web.anl.gov/PCS/acsfuel/preprint\% 20archive/Files/48_2_New\%20York_10-03_0720.pdf Retrieved October 30, 2012.

[21] Reverse Combustion: Can $\mathrm{CO} 2$ Be Turned Back into Fuel? David Biellovarious efforts are underway to find a cheap, efficient and scalable way to recycle the greenhouse gas carbon dioxide back into the hydrocarbons that fuel civilization http://www.scientificamerican.com/article.cfm?id= turning-carbon-dioxide-back-into-fuel.

[22] Private communications between Rey Sidik and J.O'M. Bockris: Cost of Methanol Production from $\mathrm{CO} 2$ and hydrogen. 2006-2008.

[23] Keith DW, Ha-Duong M. CO2 Capture From The Air: Technology Assessment and Implications for Climate Policy, Department of Engineering and Public Policy, Carnegie Mellon University, Pittsburgh, PA, 15213, USA, keith@cmu.edu

[24] There is a company located in Michigan which has reduced the price of its wind power electricity to three cents per kWh.

[25] As our MethanolAT Economy with zero global warming is not going to be active for, say, a decade, would give us time to get the price of wind to two cents/kWh which was a cost produced by the Wind Association for the USA.

[26] Bose T, Malbrunot P. Hydrogen, John Libby Euro Texts, Esher, KT009 Q.Y., UK, 2006.

Table 1 - A. Ipcc ar4 syr, Core Writing Team; Pachauri RK, Reisinger A, Eds., Climate Change 2007: Synthesis Report,
Contribution of Working Groups I, II and III to the Fourth Assessment Report of the Intergovernmental Panel on Climate Change, IPCC, 2007; ISBN 92-9169-122-4, http://www.ipcc.ch/publications_and_data/ar4/syr/en/contents .html;

B. Ipcc ar4 wg1, Solomon S, Qin D, Manning M, Chen Z, Marquis M, Averyt KB, Tignor M, Miller HL, Eds., Climate Change 2007: The Physical Science Basis, Contribution of Working Group I to the Fourth Assessment Report of the Intergovernmental Panel on Climate Change, Cambridge University Press 2007; ISBN 978-0-521-88009-1, http://www.ipcc.ch/publications and data/ar4/wg1/en/content s.html (pb: 978-0-521-70596-7);

C. Ipcc ar4 wg2, Parry ML, Canziani OF, Palutikof JP, van der Linden PJ, Hanson CE, Eds., Climate Change 2007: Impacts, Adaptation and Vulnerability, Contribution of Working Group II to the Fourth Assessment Report of the Intergovernmental Panel on Climate Change, Cambridge University Press 2007; ISBN 978-0-521-88010-7, http://www.ipcc.ch/publications_and_data/ar4/wg2/en/content s.html (pb: 978-0-521-70597-4);

D. Ipcc ar4 wg3, Metz B, Davidson OR, Bosch PR, Dave R, Meyer LA, Eds. Climate Change 2007: Mitigation of Climate Change, Contribution of Working Group III to the Fourth Assessment Report of the Intergovernmental Panel on Climate Change, Cambridge University Press 2007; ISBN 978-0-521-88011-4, http://www.ipcc.ch/publications and data/ar4/wg3/en/contents.html (pb: 978-0-521-70598-1). 